\title{
THE EFFECT OF DIET ON THE 5-HYDROXYTRYPTAMINE CONTENT OF THE SMALL INTESTINE AND OTHER ORGANS IN RATS AND MICE
}

\author{
BY \\ T. J. SULLIVAN \\ From the Department of Pharmacology and Therapeutics, St. Thomas's Hospital Medical School, \\ London
}

(RECEIVED MAY 31, 1960)

In rats, a diet of meat or liver caused a rise in the amount of 5-hydroxytryptamine in the small intestine, an increase in the weight of the intestine and a 10-fold increase in anaerobic bacteria in the rectum. A diet containing added tryptophan did not affect tissue levels of 5-hydroxytryptamine in rats, but in mice there was a rise of 5-hydroxytryptamine in various tissues. The significance of these findings is discussed together with the possible role of intestinal bacteria in mediating the effects caused by a meat diet. No change was observed in the 5-hydroxytryptamine content of brain or in the distribution of argentaffin cells in the jejunum as a result of these diets.

Cordier (1926) reported that the argentaffin cells in the intestine of mice were increased in number 5 to 10 times and showed increased granularity when the animals received a diet exclusively of raw meat for 7 to 10 weeks. Since argentaffin cells are believed to secrete 5-hydroxytryptamine (Erspamer, 1954 ; Benditt and Wong, 1957), Stacey and Sullivan (1957) studied the effect of a diet of raw meat on the 5-hydroxytryptamine content of the small intestine of rats, and reported that it was raised. They also found that the 5-hydroxytryptamine content of the small intestine in mice was raised when tryptophan was added to the diet, and concluded that the high tryptophan intake in an exclusively meat diet might account for the rise of intestinal 5-hydroxytryptamine. The present paper reports further studies on the effect of protein feeding on 5-hydroxytryptamine metabolism in rats and mice.

\section{MeTHODS}

Groups of adult male rats weighing 120 to $200 \mathrm{~g}$. or mice weighing 20 to $25 \mathrm{~g}$. were matched according to age and weight. Controls received a mixed balanced diet supplied by J. Murray and Sons, London, S.E.8, in cube or powder form, and treated groups received the experimental diet. Both groups were given unrestricted water and a vitamin supplement (Abidec drops; Parke, Davis and Co.) in their drinking water twice weekly. Both groups remained healthy, although differences in weight between control and treated groups sometimes developed during treatment.
Aliquots of a homogenate of the whole small intestine from the pyloric sphincter to the ileo-caecal junction of mice were assayed. Since the whole rat small intestine is bulky, tough and difficult to homogenize completely, the mucous membrane, which contains all the 5-hydroxytryptamine (Feldberg and Toh, 1953), was scraped off with a scalpel and homogenized; aliquots were then assayed.

The 5-hydroxytryptamine content of the small intestine and spleen was usually assayed fluorimetrically by the methods of Udenfriend, Weissbach and Clark (1955) or Weissbach, Waalkes, and Udenfriend (1958). Sometimes, as indicated in the text, 5-hydroxytryptamine was assayed biologically. Fluorescence was measure in $3 \mathrm{~N}$ hydrochloric acid, in which tryptamine and tryptophan do not fluoresce (Udenfriend, Bogdanski, and Weissbach, 1955). For bioassay, 5-hydroxytryptamine was extracted with $95 \%$ acetone and assayed on the atropinized oestrous rat uterus by the superfusion technique (Gaddum, 1953). Brain 5-hydroxytryptamine was assayed by the method of Bogdanski, Pletscher, Brodie, and Udenfriend (1956).

Since the treated animals lost weight during the experiment, results expressed on the basis of tissue weight or final body weight are fallacious. However, as body weights at the beginning of the experiment were similar for the two groups, the concentrations of 5 -hydroxytryptamine are expressed in $\mu \mathrm{g}$. $/ \mathrm{kg}$. initial body weight except where stated otherwise.

Some variation will be seen between the results obtained for control groups because of differences between them in the initial body weight. There was closer agreement when the results were expressed as $\mu \mathrm{g}$./g. tissue. 
For estimations of the 5-hydroxytryptamine content of platelets, rats were lightly anaesthetized with ether, and bled from the carotid artery either through a piece of polythene tubing not more than $2.5 \mathrm{~cm}$. long or a siliconed glass cannula. Mice were decapitated after light ether anaesthesia and the blood collected via a siliconed glass funnel into a siliconed glass tube containing $1 \mathrm{ml}$. of disodium edetate solution $(1.0$ g. $/ 100 \mathrm{ml}$. $0.7 \%$ sodium chloride). The volume of blood obtained was about $1 \mathrm{ml}$. from mice and $6 \mathrm{ml}$. from rats. Platelet-rich plasma was prepared by the method of Hardisty and Stacey (1955), except that the blood was centrifuged for $10 \mathrm{~min}$. at $160 \mathrm{~g}$. The relatively high proportion of sodium edetate present did not interfere with the fluorimetric estimation since it neither fluoresced nor caused quenching of the fluorescence due to 5-hydroxytryptamine.

Urinary excretion of 5-hydroxyindoleacetic acid was estimated on the pooled urine of groups of rats by the method of Macfarlane, Dalgliesh, Dutton, Lennox, Nyhus, and Smith (1956) after collecting urine from the rats in metabolism cages for 16 to $18 \mathrm{hr}$. overnight. For estimation of the percentage recovery of injected 5-hydroxytryptamine as 5-hydroxyindoleacetic acid, rats were injected subcutaneously with $6 \mathrm{mg} . / \mathrm{kg}$. 5-hydroxytryptamine as the creatinine sulphate after which urine was collected for 16 to $18 \mathrm{hr}$. overnight. Controls received $0.5 \mathrm{ml}$. saline subcutaneously. Urinary creatinine was estimated by the microchemical method of Folin (1914).

For observation of the rate at which 5-hydroxytryptamine was lost from the small intestine, consecutive pieces of jejunum starting from the duodenal junction, each 1.8 to $2.5 \mathrm{~cm}$. long, were incubated for $0.5,1.0,1.5$, and $2.0 \mathrm{hr}$. in Krebs Ringer phosphate solution at $37^{\circ}$ with gentle shaking. The pieces were then washed in fresh, ice-cold Krebs solution and assayed for 5-hydroxytryptamine.
In some experiments rectal swabs were taken from animals on the day they were killed. They were plated on blood agar and MacConkey's media. The former plates were incubated aerobically and the MacConkey's plates anaerobically in a McIntosh and Fildes' jar. After $24 \mathrm{hr}$. the colonies were counted.

Sections of small intestine taken for histology of the argentaffin cells were fixed in Bouin's fluid, or in $10 \%$ formol, and embedded in paraffin. The sections were stained with Masson's silver stain or by the activated Protargol method (Schofield, 1951).

\section{RESUlTS}

\section{Experiments with Meat Diet}

Rats.-Rats were fed on a diet of raw lean beef for either 10 to 23 days or 60 to 67 days before 5-hydroxytryptamine was assayed fluorimetrically. Table I shows the results of these experiments. There was a significant rise of intestinal 5-hydroxytryptamine in the meat-fed rats after both periods of treatment. The 5-hydroxytryptamine content of spleen, platelets and brain was not affected after 10 to 23 days of treatment, however.

These results were confirmed when the intestinal 5-hydroxytryptamine content of groups of rats was assayed biologically after 20,43 and 76 days on a meat diet. At the end of each of these periods of treatment the 5-hydroxytryptamine level was higher in treated than in control rats. The overall mean rise in 7 treated rats was $102 \%$, but since the numbers of animals in the 3 experiments were not strictly comparable, the overall results have not been statistically analysed.

Urinary excretion of 5-hydroxyindoleacetic acid was estimated at various times during these

TABLE I

\section{THE EFFECT OF A MEAT DIET ON THE 5-HYDROXYTRYPTAMINE CONTENT OF THE} TISSUES OF RATS IN 2 EXPERIMENTS OF DIFFERENT DURATION

Mean results are expressed as $\mu \mathrm{g}$. 5-hydroxytryptamine/kg. body weight \pm standard error, except for platelets, where results are expressed as $\mu \mathrm{g}$. 5-hydroxytryptamine $/ \mathrm{ml}$. blood. $\quad$ n.s. $=$ difference not significant $(P>0.05)$.

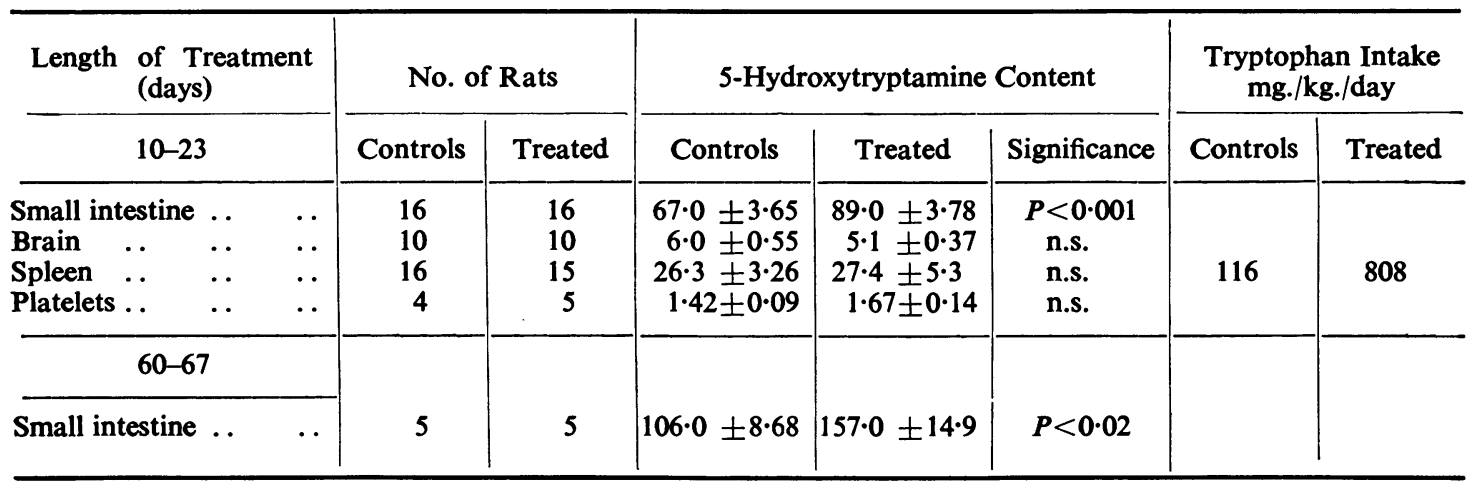


experiments. Four estimations were carried out during the first 10 days of treatment and showed no difference between the groups; the mean excretion for 6 control rats was $234 \pm 30 \mu \mathrm{g}$. $/ \mathrm{kg}$. $/$ $24 \mathrm{hr}$., and for 6 meat-fed rats $239 \pm 26 \mu \mathrm{g}$. $/ \mathrm{kg}$. $/$ $24 \mathrm{hr}$. Since it was possible that there might be a time lag before changes in 5-hydroxyindoleacetic acid excretion occurred, estimations were carried out after further periods of meat feeding. The results are shown in Table II. Although the

TABLE II

URINARY EXCRETION OF 5-HYDROXYINDOLEACETIC ACID AND CREATININE BY

6 CONTROL AND 6 MEAT-FED RATS AT VARIOUS TIMES DURING TREATMENT

\begin{tabular}{c|c|c|c|c}
\hline $\begin{array}{c}\text { Duration } \\
\text { of Treat- } \\
\text { ment } \\
\text { (days) }\end{array}$ & Group & $\begin{array}{c}5 \text {-Hydroxy- } \\
\text { indole- } \\
\text { acetic } \\
\text { Acid } \\
\mu \mathrm{g} . / \mathrm{kg} . / 24 \\
\mathrm{hr} .\end{array}$ & $\begin{array}{c}\text { Creatinine } \\
\text { mg./kg./24 } \\
\text { hr. }\end{array}$ & $\begin{array}{c}\text { 5-Hydroxy- } \\
\text { indole- } \\
\text { acetic } \\
\text { Acid/ } \\
\text { Creatinine } \\
\text { Ratio }\end{array}$ \\
\hline 11 & Control & 334 & 34 & $10 \cdot 0$ \\
\hline 17 & Meat-fed & 283 & 28 & $10 \cdot 1$ \\
\hline 51 & Control & 367 & 29 & $12 \cdot 9$ \\
& Meat-fed & 247 & 21 & $12 \cdot 1$ \\
\hline 80 & Control & 214 & 29 & $7 \cdot 5$ \\
& Meat-fed & 166 & 26 & $6 \cdot 5$ \\
\hline 169 & Control & 187 & 30 & $6 \cdot 2$ \\
& Meat-fed & 134 & 26 & $5 \cdot 3$ \\
\hline Control & 166 & 32 & $5 \cdot 2$ \\
\hline
\end{tabular}

excretion of 5-hydroxyindoleacetic acid by meatfed rats was lower throughout, excretion by both groups varied considerably. Excretion of creatinine, though lower in meat-fed rats, was less variable.

To investigate whether control and meat-fed rats metabolized injected 5-hydroxytryptamine differently, the percentage recovery of injected 5-hydroxytryptamine as urinary 5-hydroxyindoleacetic acid was studied. From 9 control rats the recovery was $28.5 \%$, and from 9 rats treated for 20 days $30.5 \%$. Erspamer (1955) gave similar figures for the recovery of injected 5-hydroxytryptamine.

In all these experiments it was found that the intestinal mucous membrane of rats which were meat-fed weighed more than in controls. The figures are shown in Table III. In the first experiment, lasting 10 to 23 days, the difference was significant. When the mucosal and muscle layers of the intestine were weighed separately it was found that in both control and treated groups the mucosal layer formed approximately the same proportion of the total weight of the intestine, namely 25 to $30 \%$, indicating that the weight increase involved both mucosal and muscle layers.

This phenomenon was not a reflection of differences in body weight between control and treated groups. As shown in Table III, the mean body weights of the groups were very close. In the second experiment, lasting 60 to 67 days, the final body weight of the meat-fed rats was a little lower than that of controls, although their intestinal mucosa was heavier.

The weight increase of the intestine did not account for the rise in 5-hydroxytryptamine content, because the mucosa of meat-fed rats

TABLE III

THE EFFECT OF A MEAT DIET ON THE WEIGHT AND 5-HYDROXYTRYPTAMINE CONTENT OF THE SMALL INTESTINAL MUCOSA AND THE BODY WEIGHT OF RATS

All results given as means \pm standard error. n.s. $=$ difference not significant $(P>0.05)$.

\begin{tabular}{|c|c|c|c|c|c|c|}
\hline \multirow{2}{*}{$\begin{array}{l}\text { Duration of } \\
\text { Treatment } \\
\text { (days) }\end{array}$} & \multirow{2}{*}{ Group } & \multirow{2}{*}{$\begin{array}{l}\text { No. of } \\
\text { Rats }\end{array}$} & \multirow{2}{*}{$\begin{array}{c}\text { Wt. of } \\
\text { Intestinal } \\
\text { Mucosa (g.) }\end{array}$} & \multirow{2}{*}{$\begin{array}{c}\text { 5-Hydroxytryptamine } \\
\mu \text { g./g. Mucosa }\end{array}$} & \multicolumn{2}{|c|}{ Body Weight (g.) } \\
\hline & & & & & Initial & Final \\
\hline 10 to 23 & $\begin{array}{l}\text { Control } \\
\text { Meat-fed }\end{array}$ & $\begin{array}{l}16 \\
15\end{array}$ & $\begin{array}{l}3 \cdot 84 \pm 0 \cdot 16 \\
4 \cdot 52 \pm 0 \cdot 13 \\
P<0 \cdot 01\end{array}$ & $\begin{array}{l}3 \cdot 30 \pm 0 \cdot 14 \\
3 \cdot 81 \pm 0 \cdot 16 \\
P<0.05\end{array}$ & $\begin{array}{l}188 \pm 5 \cdot 8 \\
194 \pm 6 \cdot 9\end{array}$ & $\begin{array}{l}210 \pm 7 \cdot 6 \\
215 \pm 6 \cdot 2\end{array}$ \\
\hline 60 to 67 & $\begin{array}{l}\text { Control } \\
\text { Meat-fed }\end{array}$ & $\begin{array}{l}5 \\
5\end{array}$ & $\begin{array}{c}3 \cdot 53 \pm 0 \cdot 21 \\
4 \cdot 14 \pm 0 \cdot 30 \\
\text { n.s. }\end{array}$ & $\begin{array}{l}3.57 \pm 0.19 \\
4.93 \pm 0.18 \\
P<0.001\end{array}$ & $\begin{array}{l}120 \pm 2 \cdot 3 \\
131 \pm 3 \cdot 7\end{array}$ & $\begin{array}{l}241 \pm 0 \cdot 6 \\
231 \pm 3 \cdot 5\end{array}$ \\
\hline
\end{tabular}


contained more 5-hydroxytryptamine per g. of tissue than did control mucosa (Table III).

Since it was thought possible that alterations of intestinal bacterial flora due to meat-feeding might contribute towards the rise in weight of the intestine or in its 5-hydroxytryptamine content, rectal swabs were taken from 9 control and 9 meat-fed rats. The growth of aerobes was qualitatively and quantitatively similar in treated and control groups, but the anaerobic growth was much more profuse in meat-fed rats. The ratio of the number of anaerobic colonies after $24 \mathrm{hr}$. incubation between meat-fed and control rats was of the order of $10: 1$. Qualitative differences were not investigated.

In view of the histological findings in meat-fed mice reported by Cordier (1926), sections of jejunum from control and treated rats were stained for argentaffin cells. In control specimens under the oil immersion (magnification $\times 1,000$ ) 425 argentaffin cells were counted in 400 fields, or 1.06 cells/field. In the intestine of meat-fed rats there were 392 argentaffin cells in 420 fields, or 0.94 cells / field. No difference in the number of granules in the argentaffin cells of the two groups was observed. An attempt was made to count the number of granules per cell, but in many cases the intensity of granulation made it impossible to distinguish individual granules. No other histological differences between the intestines of meatfed and control animals were seen.

Mice.-An attempt was made to repeat the experiment of Cordier on the effect of meat-feeding for 7 to 10 weeks on the argentaffin cells of mice, and to estimate intestinal 5-hydroxytryptamine in addition. By the end of 9 weeks, however, only 2 of the meat-fed mice remained alive. Very few argentaffin cells were seen in stained sections of jejunum. Under the oil immersion (magnification $\times 1,000) 8$ cells were seen in 50 fields in the controls, and 2 in 50 fields in meat-fed mice. The number of surviving mice was too small for any comparison of intestinal 5-hydroxytryptamine content to be made.

\section{Experiments with Tryptophan Feeding}

Rats.-By measuring the food intake and using the analytical data of Block and Weiss (1956) it was calculated that the mean dietary tryptophan intake of meat-fed rats was considerably higher than that of the controls (Table I).

If the effect of raising the intestinal 5-hydroxytryptamine of rats as a result of meat-feeding was due to the increased dietary tryptophan intake, it should be possible to reproduce the effect by adding tryptophan to the ordinary diet. Treated rats therefore received the normal diet of rat cubes crushed into powder form to which $1 \%$ DL-tryptophan had been added, controls receiving crushed cubes alone.

Three experiments of varying duration were carried out. No change in intestinal 5-hydroxytryptamine was found. Results are shown in Table IV in which rats treated for $22,28,40,60$, and 61 days are grouped together for convenience. It will be seen that the tryptophan intake of treated rats was many times greater than that of controls. The 5-hydroxytryptamine content of spleen and brain was also assayed in these animals. but no differences were found between treated and controls. No difference in the weight of the intestine was found between the two groups.

Recovery of injected 5-hydroxytryptamine and serial 5-hydroxyindoleacetic acid estimations did not reveal any differences between controls and tryptophan-fed rats.

TABLE IV

THE EFFECT OF $1 \%$ TRYPTOPHAN ADDED TO THE CONTROL DIET ON THE 5-HYDROXYTRYPTAMINE CONTENT OF THE SMALL INTESTINE OF RATS IN 3 EXPERIMENTS OF DIFFERENT DURATION

Results are expressed as means \pm standard error.

\begin{tabular}{|c|c|c|c|c|c|c|}
\hline \multirow{2}{*}{$\begin{array}{l}\text { Duration of } \\
\text { Treatment } \\
\text { (days) }\end{array}$} & \multicolumn{2}{|c|}{ No. of Rats } & \multicolumn{2}{|c|}{$\begin{array}{l}\text { 5-Hydroxytryptamine } \\
\text { Content } \\
\mu \mathrm{g} . / \mathrm{kg} . \text { Body Weight }\end{array}$} & \multicolumn{2}{|c|}{$\begin{array}{l}\text { Tryptophan Intake } \\
\text { mg./kg./day }\end{array}$} \\
\hline & Controls & Treated & Controls & Treated & Controls & Treated \\
\hline $\begin{array}{rr}10 \text { to } & 15 \\
22,, & 61 \\
144,, & 161\end{array}$ & $\begin{array}{r}6 \\
10 \\
5\end{array}$ & $\begin{array}{r}5 \\
10 \\
6\end{array}$ & $\begin{array}{l}61 \cdot 0 \pm 6 \cdot 79 \\
64 \cdot 0 \pm 3 \cdot 43 \\
73 \cdot 5 \pm 0 \cdot 63\end{array}$ & $\begin{array}{l}59 \cdot 0 \pm 2 \cdot 49 \\
67 \cdot 5 \pm 5 \cdot 47 \\
78 \cdot 0 \pm 7 \cdot 02\end{array}$ & $\begin{array}{l}116 \\
112 \\
109\end{array}$ & $\begin{array}{r}1,246 \\
832 \\
760\end{array}$ \\
\hline
\end{tabular}


Bacterial growth from rectal swabs was studied. No qualitative or quantitative difference was found between the two groups in aerobic growth. Anaerobic growth from swabs of tryptophan-fed rats was 2.5 times that of the controls.

Mice.-Treated mice received 1\% DL-tryptophan in their diet in one experiment for 10 to 12 days and in another for 61 to 63 days. Table $\mathrm{V}$ shows the results obtained. In both experiments the 5-hydroxytryptamine content of the small intestine and spleen was significantly raised in the treated mice. Brain 5-hydroxytryptamine was unaffected. Platelet 5-hydroxytryptamine was assayed in the shorter experiment and also found to be raised. The mean weight of the intestine was the same in the 2 groups.

Calculation of the dietary tryptophan intake showed that treated mice had a very much higher intake than controls.

TABLE V

THE EFFECT OF $1 \%$ TRYPTOPHAN ADDED TO THE CONTROL DIET ON THE 5-HYDROXYTRYPTAMINE CONTENT OF THE TISSUES OF MICE IN 2 EXPERIMENTS OF DIFFERENT DURATION

Mean results are expressed as $\mu$ g. 5-hydroxytryptamine $/ \mathrm{kg}$. body weight \pm standard error, except for platelets, where results are expressed as $\mu$ g. 5-hydroxytryptamine/ml. blood. n.s. $=$ difference not significant $(P>0 \cdot 05)$.

\begin{tabular}{|c|c|c|c|c|c|c|c|}
\hline \multirow{2}{*}{$\frac{\begin{array}{c}\text { Length of } \\
\text { Treatment (days) }\end{array}}{10-12}$} & \multicolumn{2}{|c|}{ No. of Mice } & \multicolumn{3}{|c|}{ 5-Hydroxytryptamine Content } & \multicolumn{2}{|c|}{$\begin{array}{c}\text { Tryptophan Intake } \\
\text { mg./kg./day }\end{array}$} \\
\hline & Controls & Treated & Controls & Treated & Significance & Controls & Treated \\
\hline $\begin{array}{lll}\text { Small intestine } & \ldots \\
\text { Brain } & \ldots & \ldots \\
\text { Spleen } & \ldots & \ldots \\
\text { Platelets } & . & \ldots\end{array}$ & $\begin{array}{l}19 \\
10 \\
11 \\
10\end{array}$ & $\begin{array}{l}19 \\
10 \\
11 \\
10\end{array}$ & $\begin{array}{l}172 \pm 14 \cdot 1 \\
17 \cdot 3 \pm 0.69 \\
59 \pm 9.42 \\
3.25 \pm 0.28\end{array}$ & $\begin{array}{c}221 \pm 14.0 \\
17.3 \pm 1.36 \\
108 \pm 10.6 \\
4.78 \pm 0.39\end{array}$ & $\begin{array}{c}P<0.05 \\
\text { n.s. } \\
P<0.01 \\
P<0.01\end{array}$ & 230 & 1,132 \\
\hline $61-63$ & \multirow[b]{2}{*}{$\begin{array}{l}8 \\
8 \\
8\end{array}$} & \multirow[b]{2}{*}{$\begin{array}{l}7 \\
6 \\
7\end{array}$} & \multirow[b]{2}{*}{$\begin{array}{cl}206 & \pm 18 \cdot 8 \\
16 \cdot 3 & \pm 1 \cdot 42 \\
100 & \pm 16 \cdot 1\end{array}$} & \multirow[b]{2}{*}{$\begin{array}{c}315 \pm 35 \cdot 0 \\
16 \cdot 5 \pm 2 \cdot 23 \\
168 \pm 19 \cdot 3\end{array}$} & \multirow[b]{2}{*}{$\begin{array}{c}P<0.01 \\
\text { n.s. } \\
P<0.02\end{array}$} & \multirow[b]{2}{*}{248} & \multirow[b]{2}{*}{1,194} \\
\hline $\begin{array}{lcc}\text { Small intestine } & . . \\
\text { Brain } & . . & . . \\
\text { Spleen } & . & .\end{array}$ & & & & & & & \\
\hline
\end{tabular}

TABLE VI

THE EFFECT OF OTHER HIGH-PROTEIN DIETS ON THE 5-HYDROXYTRYPTAMINE CONTENT OF THE TISSUES OF RATS

Mean results are expressed as $\mu$ g. 5-hydroxytryptamine $/ \mathrm{kg}$. body weight \pm the standard error. n.s. $=$ difference not significant $(P>0.05)$.

\begin{tabular}{|c|c|c|c|c|c|c|c|}
\hline \multicolumn{3}{|c|}{ Diets of Groups } & No. of Rats & Small & Spleen & Brain & $\begin{array}{c}\text { Tryptophan } \\
\text { Intake }\end{array}$ \\
\hline $\begin{array}{ll}\text { Control } & \ldots \\
\text { Liver } & \ldots\end{array}$ & $\begin{array}{l}. . \\
.\end{array}$ & $\begin{array}{l}. . \\
\cdots\end{array}$ & $\begin{array}{l}8 \\
8\end{array}$ & $\begin{array}{c}100 \pm 3.64 \\
151 \pm 13.5 \\
P<0.01\end{array}$ & $\begin{array}{c}15 \cdot 6 \pm 1 \cdot 36 \\
12 \cdot 4 \pm 1 \cdot 13 \\
\text { n.s. }\end{array}$ & $\begin{array}{c}5 \cdot 7 \pm 0.48 \\
5 \cdot 0 \pm 0.25 \\
\text { n.s. }\end{array}$ & $\begin{array}{l}126 \\
324\end{array}$ \\
\hline $\begin{array}{l}\text { Control .. } \\
\text { Soya Bean }\end{array}$ & $\begin{array}{l}\ldots \\
\ldots\end{array}$ & $\begin{array}{l}\cdots \\
\cdots\end{array}$ & $\begin{array}{l}5 \\
5\end{array}$ & $\begin{array}{c}91 \cdot 0 \pm 5.05 \\
91 \cdot 5 \pm 12 \cdot 4 \\
\text { n.s. }\end{array}$ & $\begin{array}{c}16 \cdot 6 \pm 2 \cdot 24 \\
15 \cdot 9 \pm 1 \cdot 27 \\
\text { n.s. }\end{array}$ & - & $\begin{array}{l}112 \\
265\end{array}$ \\
\hline $\begin{array}{l}\text { Control ... } \\
\text { Calcium caseinat }\end{array}$ & te & $\begin{array}{l}. . \\
\ldots\end{array}$ & $\begin{array}{l}6 \\
5\end{array}$ & $\begin{array}{c}61.0 \pm 6.81 \\
59.0 \pm 6.65 \\
\text { n.s. }\end{array}$ & $\begin{array}{c}41 \cdot 5 \pm 2 \cdot 22 \\
51 \cdot 5 \pm 9 \cdot 54 \\
\text { n.s. }\end{array}$ & - & $\begin{array}{l}116 \\
481\end{array}$ \\
\hline
\end{tabular}




\section{Other Protein-feeding Experiments}

Although meat-feeding of rats produced a significant rise of intestinal 5-hydroxytryptamine, this did not occur in tryptophan-fed rats. The reason for this discrepancy was investigated by feeding high-protein diets in various forms to rats.

Diets composed of ox liver, soya bean flour, and calcium caseinate were fed to groups of rats, matched with controls, for 10 to 20 days, and the results of 5-hydroxytryptamine assays are shown in Table VI.

Only the liver diet produced a rise of the 5-hydroxytryptamine content of the small intestine. As with meat-fed rats, the weight of the intestinal mucosa of liver-fed rats was greater than in controls, the mean weights being $4.52 \pm 0.09 \mathrm{~g}$. and $4.07 \pm 0.19$ g. respectively $(P<0.1)$.

Calcium caseinate proved to be a very inadequate diet, since the treated rats lost $15.5 \%$ of their body weight while controls gained $9 \%$. This was reflected in the relative weights of the intestinal mucosa, the mean weight for controls being $3.44 \pm 0.28 \mathrm{~g}$. and of treated rats $2.55 \pm$ $0.17 \mathrm{~g}$. As shown in Table VI, the intestinal 5-hydroxytryptamine content of rats fed with calcium caseinate expressed as $\mu \mathrm{g}$. $/ \mathrm{kg}$. body weight differed little from that of controls. The diminution of intestinal size and weight due to inanition did not affect the total 5-hydroxytryptamine content, but there was a higher concentration per g. of mucosa. The mean 5-hydroxytryptamine content of treated rats was $4.11 \pm 0.10 \mu \mathrm{g}$. $/ \mathrm{g}$. and of controls $3.06 \pm 0.18 \mu \mathrm{g}$. $/ \mathrm{g}$. of mucosa $(P<0.05)$.

No differences between control and treated rats were found in the 5-hydroxytryptamine content of spleen or brain. On all these diets, the tryptophan intake of the treated rats was appreciably higher than that of their controls.

\section{Gut Incubation Experiments}

To investigate whether there was any difference between treated and control animals in the rate at which the small intestine gave up 5-hydroxytryptamine into the surrounding medium, pieces of jejunum were incubated as described in "Methods." Experiments were performed on intestine from 3 meat-fed rats, 2 tryptophan-fed rats and 2 tryptophan-fed mice, all of which were matched with controls. In all experiments the rate of loss was about the same for treated and control animals.

\section{Discussion}

The results show that a meat diet caused a rise of intestinal 5-hydroxytryptamine in rats and that a liver diet had a similar effect. Since meat feeding in rats produced no effect on the 5-hydroxytryptamine content of the spleen or platelets or on the urinary excretion of 5-hydroxyindoleacetic acid, it seems likely that the effect of this diet was a local one, increasing the storage of 5-hydroxytryptamine in the intestine. The addition of tryptophan to the diet of rats, however, did not affect the 5-hydroxytryptamine content in any of the tissues examined, nor was it affected by feeding the rats on a diet of soya bean flour or calcium caseinate, both of which provided diets rich in tryptophan. The failure of these tryptophan-rich diets to raise intestinal 5-hydroxytryptamine makes it unlikely that the high tryptophan content of the meat diet was wholly responsible for this change. However, the fact that tryptophan supplied in the form of meat may have been better absorbed or better utilized than when added to the ordinary diet cannot be excluded. In this connexion it may be significant that ox muscle contains $77 \mu \mathrm{g}$. pyridoxine $/ 100 \mathrm{~g}$. and ox liver $170 \mu \mathrm{g} . / 100 \mathrm{~g}$., whereas the diet received by control rats was largely composed of cereals and unlikely to contain more than $40 \mu \mathrm{g}$. pyridoxine/100 g. (data from Bicknell and Prescott, 1953).

A large increase in the anaerobic bacterial flora was found in the intestine of meat-fed rats. Mitoma, Weissbach, and Udenfriend (1956) have shown that hydroxylation to 5-hydroxytryptophan is one of the major metabolic pathways for tryptophan in Chromobacterium violaceum. Many organisms, including the common intestinal organism E. coli (Stephenson, 1949), are capable of metabolizing tryptophan, although the pathways involved have so far been incompletely defined, while conversely certain bacteria have been shown to be capable of synthesizing tryptophan (Clifton, 1957). Possibly, therefore, in the altered state of the intestinal bacterial flora in meat-fed rats, bacterial activity might result in both increased formation and hydroxylation of tryptophan.

Another possible mechanism by which bacteria might have affected intestinal 5-hydroxytryptamine is by causing an inflammatory reaction. Zbinden and Pletscher (1958) reported that chronic irritation of the stomach and small intestine of rabbits by continuous administration of ethyl alcohol often led to an increase in the 5-hydroxytryptamine content.

It was also observed that a meat diet caused an increase in the weight of the intestine of rats. It has been reported that the small intestine in germfree chicks weighs much less than in controls, and also that the intestinal weight could be significantly reduced by antibiotic feeding, while the body 
weight of the chicks was increased (Stokstad, 1954). It was suggested that the normal animal has a chronic inflammation of the intestine. In meatfed rats, the great increase of the anaerobic flora might, conversely, have exacerbated such chronic intestinal inflammation as might exist in the normal rat. In tryptophan-fed rats there was no increase in intestinal weight and a much smaller increase in anaerobic bacteria compared with meat-fed rats.

Eber and Lembeck (1958) reported a significant difference in the intestinal 5-hydroxytryptamine content of groups of rats fed on tryptophan-rich and tryptophan-poor diets. In the experiments described here, the addition of tryptophan to the diet had no effect on the 5-hydroxytryptamine content of rat tissues, but the controls did not receive a tryptophan-poor diet, which perhaps accounts for the lack of any difference between control and treated rats. A possible reason for the poor response of tissue 5-hydroxytryptamine levels to diets rich in tryptophan is that hydroxylation proceeds at a maximal rate even on a normal tryptophan intake (Udenfriend, Titus, Weissbach, and Peterson, 1956). Tryptophan-deficient diets are reported to cause significant reduction in intestinal 5-hydroxytryptamine in a number of species (Eber and Lembeck, 1958; Zbinden, Pletscher, and Studer, 1958) although these authors stress that the decrease in the 5-hydroxytryptamine content develops slowly.

A marked species difference was found in the relative effects in rats and mice of a tryptophanrich diet. While no effect was produced in rats, there was a widespread rise of the 5-hydroxytryptamine content in mice, affecting the small intestine, spleen and blood platelets. Such a generalized effect on the 5-hydroxytryptamine content of mice suggests that the diet caused an increase in 5-hydroxytryptamine synthesis in these animals.

Tryptophan feeding did not affect the brain concentration of 5-hydroxytryptamine, whereas Zbinden et al. (1958) found that brain 5-hydroxytryptamine was reduced in rabbits, guinea-pigs, rats and mice which received a tryptophan-deficient diet.

The observation of Cordier (1926) that the number of argentaffin cells in mice was increased by meat-feeding was not confirmed in these experiments, nor was any increase found in argentaffin cells of rats as a result of meat-feeding. Zbinden and Pletscher (1958) found that in rabbits the increase in 5-hydroxytryptamine caused by ethyl alcohol was only in some instances accompanied by a moderate rise in the number of argentaffin cells. Zbinden et al. (1958) found that only in severe tryptophan deficiency were the histochemical reactions of the argentaffin cells diminished. It seems, therefore, that effects upon intestinal 5-hydroxytryptamine are not commonly associated with changes in the argentaffin cell count. This is confirmed by Benditt and Wong (1957), who found that a relatively high 5-hydroxytryptamine concentration, greater than $1 \mathrm{mg} . / \mathrm{ml}$., is required before argentaffin cells can be stained by silver and azo dyes.

I wish to thank Professor R. Hare for facilities and advice on bacteriological studies, Dr. G. C. Schofield of the University of Otago, and Dr. H. Spencer for advice and assistance with histological studies, and Professor R. S. Stacey for advice and criticism of this paper.

\section{REFERENCES}

Benditt, E. P., and Wong, R. L. (1957). J. exp. Med., 105, 509 .

Bicknell, F., and Prescott, F. (1953). The Vitamins in Medicine, 3rd ed., p. 103. London: W. Heinemann Ltd.

Block, R. J., and Weiss, K. W. (1956). Amino Acid Handbook. Springfield: Charles C. Thomas.

Bogdanski, D. F., Pletscher, A., Brodie, B. B., and Udenfriend, S. (1956). J. Pharmacol. exp. Ther., $117,82$.

Clifton, C. E. (1957). Introduction to Bacterial Physiology. New York: McGraw-Hill Book Co. Inc.

Cordier, R. (1926). Arch. Biol., Paris, 36, 427.

Eber, O., and Lembeck, F. (1958). Pflüg. Arch. ges. Physiol., 265, 563.

Erspamer, V. (1954). Pharmacol. Rev., 6, 425. (1955). J. Physiol. (Lond.), 127, 118.

Feldberg, W., and Toh, C. C. (1953). Ibid., 119, 352.

Folin, O. (1914). J. biol. Chem., 17, 469.

Gaddum, J. H. (1953). Brit. J. Pharmacol., 8, 321.

Hardisty, R. M., and Stacey, R. S. (1955). J. Physiol. (Lond.), 130, 711.

Macfarlane, P. S., Dalgliesh, C. E., Dutton, R. W., Lennox, B., Nyhus, L. M., and Smith, A. N. (1956). Scot. med. J., 1, 148.

Mitoma, C., Weissbach, H., and Udenfriend, S. (1956). Arch. Biochem., 63, 122.

Schofield, G. C. (1950-51). Act. anat., 11, 414.

Stacey, R. S., and Sullivan, T. J. (1957). J. Physiol. (Lond.), 137, 63P.

Stephenson, M. (1949). Bacterial Metabolism, 3rd ed., p. 127. London: Longmans, Green and Co. Ltd.

Stokstad, E. L. R. (1954). Physiol. Rev., 34, 25.

Udenfriend, S., Bogdanski, D. F., and Weissbach, H. (1955). Science, 122, 972. Weissbach, H., and Clark, C. T. (1955). J. biol. Chem., 215, 337.

Titus, E., Weissbach, H., and Peterson, R. E. (1956). Ibid., 219, 335.

Weissbach, H., Waalkes, T. P., and Udenfriend, S. (1958). Ibid., 230, 865.

Zbinden, G., and Pletscher, A. (1958). Schweiz. Z. Path., 21, 1137 . 615 . 